University of Nebraska - Lincoln

DigitalCommons@University of Nebraska - Lincoln

Faculty Publications, Department of Psychology

Psychology, Department of

2013

Fathers, Divorce, and Child Custody

Matthew M. Stevenson

Sanford L. Braver

Ira M. Ellman

Ashley M. Votruba

Follow this and additional works at: https://digitalcommons.unl.edu/psychfacpub

Part of the Family Law Commons, and the Psychology Commons

This Article is brought to you for free and open access by the Psychology, Department of at

DigitalCommons@University of Nebraska - Lincoln. It has been accepted for inclusion in Faculty Publications, Department of Psychology by an authorized administrator of DigitalCommons@University of Nebraska - Lincoln. 
Published as chapter 21 in Handbook of Father Involvement: Multidisciplinary Perspectives, 2nd edition (Natasha J. Cabrera and Catherine S. Tamix-LeMonda, editors), pp. 379-396, New York: Routledge/Taylor \& Francis Group, 2013.

Copyright (C) 2013 Taylor \& Francis. Used by permission.

\title{
Fathers, Divorce, and Child Custody
}

\author{
Matthew M. Stevenson, Sanford L. Braver, Ira M. Ellman, \\ and Ashley M. Votruba
}

Arizona State University

\section{Historical Overview and Theoretical Perspectives}

\section{Introduction}

A great many fathers will have their fathering eliminated, disrupted, or vastly changed because they become divorced from the child's mother. In fact, between $40 \%$ and $50 \%$ of marriages end in divorce (Cherlin, 2010). Although the divorce rate (measured as divorces per 1,000 people) is high by the standards prior to the late 1960s, it has actually fallen more than $30 \%$ since its peak in 1980. The decline in divorce rates in recent years has, however, been concentrated among the college-educated portion of the population; divorce rates among the less well educated may have even increased (Cherlin, 2010). But for both groups, divorce remains the most prevalent reason for changes in paternal parenting opportunities. For almost all divorced fathers (as well as for most mothers and children), divorce is a life-defining event, around which all other experiences are organized: before the divorce versus after the divorce. Although mothers' parenting is generally changed by divorce, the revision to the parent-child interaction patterns is generally not as far-reaching as it is to fathers' (Braver \& Lamb, in press; Braver, Shapiro, \& Goodman, 2005; Fabricius, Braver, Diaz, \& Velez, 2010). The reason, of course, is the radical difference between the two parents' custodial arrangements that typically occurs. As will be documented more precisely below, mothers generally become chief custodians of children, with fathers having visiting rights only. Although that situation has changed in recent 
years, due in large part to the fact that research has accumulated that illuminates the unintended negative consequences of that practice on fathers and children, it remains normative. Thus, no review of fathers and divorce can be complete or enlightening unless it also considers custody matters, as we do here.

\section{Child Custody Distinctions}

A number of distinctions concerning child custody are important to understand. Legal custody refers to the right to make decisions regarding medical care, education, religion, etc., of the child, whereas physical custody refers to the living arrangements, and rights and responsibilities for the daily care of the child. With respect to legal custody, joint legal custody allows a continuation of decision-making authority the parents had before the divorce: either parent may make these parental decisions. In practice, this arrangement requires some degree of coordination and agreement between the parents. Sole legal custody, in contrast, grants major decision making rights exclusively to one parent, the "custodial" parent, who is solely authorized to make decisions regarding the child without regard to the views of the other parent. With respect to physical custody, in joint physical custody, the child spends substantial time living with each parent. Time splits in the latter are often not 50\%-50\%; time distributions as unequal as $30 \%-70 \%$ are often deemed joint physical custody (Kelly, 2007; Venohr \& Griffith, 2005). With sole physical custody, the child lives primarily with one parent, with the other (noncustodial or nonresidential) parent typically having visitation rights, such as on weekends, holidays, and vacations. There is a natural association between the two divisions of custody: Joint physical custody parents almost always share joint legal custody, as well; but parents with joint legal custody mayor may not also have joint physical custody.

\section{History of Child Custody Standards}

Child custody policies have changed greatly over the course of history, generally following the prevailing gender roles of the time (Braver \& O'Connell, 1998; Mason, 1994). English law originally followed Roman practice and applied a broad preference for paternal custody (but English law at this time did not allow divorce except by Act of Parliament, which means occasions on which to apply the rule were limited). By the early nineteenth century, however, American courts were applying the "tender years doctrine," under which it was presumed best to place young children with their mothers (sometimes combined with a preference for placing older children with their fathers), and this became the dominant rule for much of the twentieth century. However, reform beginning in the 1960s eventually led all states to adopt the Best Interest of the Child standard (BIS), in which what should prevail was whatever arrangement was deemed best for the child (Ellman et al., 2010). While there is some variation among the states, the version of BIS set out in 1970 by the Uniform Marriage and Divorce Act is broadly representative. It specifies that in determining the child's best interests, a court should consider: (a) the wishes of the child's parents as to custody; (b) the wishes of the child as to custody; (c) the interaction and relationship of the child with his parents, his siblings, and any person who may significantly affect the child's best interest; (d) the child's adjustment to his home, school, and community; and (e) the mental and physical health of all individuals involved. The 
BIS also has been adopted internationally by the United Nations under article 9.1 of the United Nations Convention of the Rights of the Child (1989).

The BIS has generally been viewed as an improvement over past standards because it focuses on the needs and interests of children as the impetus for custody decisions rather than on justice for the parents, the gender or parental rights of the parents, or other standards (Schepard, 2004). In addition, the BIS has been praised for being flexible, simple, and egalitarian, and for allowing individualized decision making (Chambers, 1984; Warshak, 2007). However, considerable criticism has also been leveled at the BIS because its definition of children's best interests is so vague (Emery, Otto, \& O'Donohue, 2005; Tippins \& Wittman, 2005). Some have argued that the ambiguity of that standard enables judges to rely on idiosyncratic biases and subjective value judgments (Chambers, 1984); allows judges to favor one gender (mothers: Warshak, 2007; fathers: Polikoff, 1982); and that the unpredictability of judicial outcomes due to BIS promotes custody litigation (O'Connell, 2007). Several hotly debated alternative child custody standards have been proposed to address various perceived drawbacks of the BIS and are discussed at length in a recent book chapter (Fabricius et al., 2010) but are beyond the scope of the present chapter.

\section{Theoretical Perspectives}

Attachment theory is important with respect to child custody, in that custody standards have continually sought to maintain close relationships between one or both parents with their children following divorce. Implicit in custody decisions is the importance of high quality parenting to enable strong, positive relationships to form between parents and their children. Although early theories of attachment focused on mother-child attachment (interestingly child custody statistics also favored mothers), more recently theorists have begun to consider the unique role played by the father in the exploration system (Paquette, 1994). In this sense, the father is thought to open children up to the world and promote exploration, particularly in arousing play contexts that improve children's ability to assess and take risks, improve social skills, and reduce inappropriate aggression in social contexts. This perspective of the father as an agent to further exploration places the father in a complimentary role to the mother, considered more apt to provide comfort, soothing, and a secure base in times of distress. Thus, recent theoretical advances argue that children receive complimentary benefits from both mothers and fathers, provided both parents are fit to parent.

Family systems theory (Cox \& Paley, 1997) holds that the functioning of any relationship in a family is influenced by the characteristics of relationships in other family subsystems, through the principle of interdependence. For example, parents engaging in conflict, whether before or after divorce, negatively affect the quality of parent-child relationships. Family systems theory is near-ubiquitous in guiding research on divorce, parent conflict, and child outcomes and has some influence in custody law. For example, some states have a "friendly parent" provision in custody statutes, which favors the parent who is more likely to encourage continuing child contact with the other parent. 


\section{Current Research Questions}

We believe that the most important issue confronting custody research concerns the BIS and its application in current practice and policy. After a brief overview of measurement issues in child custody research, we next examine, under the heading "Empirical Findings," the following issues about which research has provided rather firm answers: (a) What are the rates of various child custody arrangements? (b) What is the process of obtaining a custody arrangement? (c) What factors impact children's adjustment postdivorce? (d) What measures are currently used in custody evaluations under the BIS? (e) Do other measures exist in psychological research that can be used to improve custody evaluations? (f) Are there empirically based intervention programs in existence that improve parenting and children's outcomes? Finally, we conclude with sections on "Bridges to Other Disciplines," "Policy Implications," and "Future Directions."

\section{Research Measurement and Methodology}

We should begin by noting one limitation in our discussion of measurement in custody decision making. Custody decisions necessarily involve value judgments as well as factual assessments. For example, courts must consider values about which parents may differ: whether parents want their children to be religious or freethinking, spirited or compliant, aggressive or modest, creative or conventional. Parents of different religious faiths may have conflicting views on what their children should be taught to believe. Some parents want their children to appreciate and accept diversity in sexual orientation, but others want them to view heterosexuality as morally superior to homosexuality. Courts have often struggled when required to resolve value conflicts of this kind, and with good reason (Ellman, 1999a, 2003; Ellman et al., 2010). Such conflicts over values are beyond the scope of this chapter to the extent they do not have an impact on child outcome variables that existing research findings can measure with accepted indicators of child maladjustment (such as mental health problems), or developmental competence (Masten \& Coatsworth, 1998) (such as indicators of success in developmental tasks like school or employment). Our operational definition of the child's best interests is therefore positive outcomes on measures of child adjustment, mental health, and developmental competence.

In a later section, we also review and critique measures that are common in child custody evaluations by professional psychologists, and suggest other factors that could and should be measured.

\section{Empirical Findings}

\section{Child Custody Statistics}

Several studies have examined jurisdiction, state, and national-level data on physical and legal custody rates in the United States and found that custody arrangements differ drastically between mothers and fathers, as noted in the introduction. Joint physical custody of children was 
specified in only $2 \%-6 \%$ of cases, fathers received primary physical custody in $8 \%-14 \%$ of cases, while in fully $68 \%-88 \%$ of cases, mothers received primary physical custody (Argys et al., 2007; Braver \& O'Connell, 1998; Maccoby \& Mnookin, 1992; Seltzer, 1990). However, research suggests that the amount of time specified with nonresident parents has generally increased in recent decades. Before the 1980s, most decrees specified the traditional pattern: that children should spend every other weekend with the nonresident parent, which is about $14 \%$ of children's time (Kelly, 2007). Two methodologically identical studies on randomly selected case files in Arizona the late-80s and late-90s, respectively (Braver \& O'Connell, 1998; DeLusé, 1999) found the decade was marked by increases in the parenting time ordered, such as added visitation during the week, and uninterrupted weeks with the nonresidential parent during the summer. The present century registered even further increases. A review of randomly selected cases in Arizona for divorces filed in 2001-2002, indicated that about half of the decrees specified $24 \%-32 \%$ of the days of the year for noncustodial parenting time, and another fifth specified 33\%-50\% of the days of the year (Venohr \& Griffith, 2003). Fewer than one fifth of the cases specified as little as the formerly traditional every-other-weekend. By 2008, 29\% of decrees specified more than $35 \%$ of time with the nonresident parent and parenting time was essentially equally divided in about $22 \%$ of those cases (Venohr \& Kaunelis, 2008). The recent increase in Arizona nonresidential parenting time appears to be matched in other states: $24 \%$ of divorcing parents in Wisconsin had equal parenting time according to 2003 data (Brown \& Cancian, 2007), and $46 \%$ of fathers in Washington state received at least $35 \%$ parenting time in 2007-2008 (George, 2008).

With respect to joint legal custody, rates appear to be more variable from state to state, ranging from as low as $21 \%$ (Seltzer, 1990) to as high as $76 \%$ (Maccoby \& Mnookin, 1992) and $93 \%$ (Douglas, 2003). However, joint legal custody rates also seem to be generally increasing over time, despite their increased variability (Braver et al., 2005). Interestingly, changes in rates of legal and physical custody appear to be informal and unofficial rather than resulting from a formal rule change (Fabricius et al., 2010).

\section{Process of Obtaining a Divorce and a Custody Arrangement}

Every state has statutes that provide its courts with authority to determine the custody of children when their parents separate. Custody law makes no distinction between divorcing parents and unmarried parents, once the identity of the legal father is established, and about onethird of custody decrees issued by family courts involve unmarried parents. Although a judicial decree setting forth the custody arrangement is the final result of any case, the standard procedure for reaching that result varies among states. The dominant trend is away from the traditional adversarial system employed in normal civil litigation. Contested custody contests in which a judge must decide between competing parental claims are relatively rare; for example, a California study found 25 years ago that more than $78 \%$ of divorcing parents agreed on their custody arrangement from the very beginning of their case (Maccoby \& Mnookin, 1992). Most of the rest come to an agreement before a judge was asked to decide; studies find judicial resolution of a contested custody dispute occurs in only $2 \%-10 \%$ of divorces (Braver \& O'Connell, 1998; Maccoby \& Mnookin, 1992). 
A variety of forces push parents to agree. In many states, the courts themselves adopt a variety of measures to encourage them to do so-and to discourage them from asking for judicial resolution. Semple (2011) notes that this "settlement mission" (the effort to bring about a voluntary resolution between the adult parties) has largely replaced the courts' former "analytical mission" (the effort to determine what parenting arrangement would be in the best interests of the child or children involved; i.e., to determine the "right answer"). Mediation, in which a neutral professional facilitates the resolution of custody, parenting time, and other child-related disputes, is often required of the parents before they may have access to judicial resolution (Braver \& O'Connell, 1998). Judges may meet with parties before the mediation to impress upon them the importance of coming to agreement to their children. (For more on mediation and dispute resolution see Applegate, Schwartz, \& Holtzworth-Munroe, this volume). There is general agreement among professionals that a negotiated or mediated settlement is better for children than the judicial resolution of custody contests, which many believe can promote long-lasting and deleterious parental conflict (Pruett \& Jackson, 1999). Some studies have found that no attorney at all was involved in about $30 \%$ of divorces, and only one attorney in an additional 30\% (Braver \& O'Connell, 1998); thus the proportion of two-attorney cases appears to be decreasing, although this differs by state. In recent years, parent education classes have become more commonplace in an attempt to help facilitate negotiations, improve parental agreements, and prevent parents from litigating; yet there is little evidence that they are achieving the intended effect (Goodman, Bonds, Sandler, \& Braver, 2004; Sigal, Sandler, Wolchik, \& Braver, 2011).

In $5 \%-10 \%$ of cases, an expert (usually a psychologist) is hired by the parents to evaluate the family and make nonbinding custody recommendations, often first to the parents and later to the court if settlement is not reached (Gould \& Martindale, 2007). However, the legal and ethical propriety, and scientific basis of custody evaluations remains hotly debated (Bow \& Quinell, 2004; Emery et al., 2005; Kelly \& Ramsey, 2009; Tippins \& Wittman, 2005). More discussion of custody evaluations follow later.

The fact that most custody arrangements result from parental agreement does not mean the legal rules are unimportant, because they may influence the terms of the parents' agreement. Parents may also be influenced by what they are told by the professionals (i.e., attorneys, mediators, custody evaluators, parent educators) they encounter along the way. Accordingly, alterations in the professional standards regarding custody, such as we recommend, may still have an important impact on custody arrangements.

\section{Research on Child Outcomes after Divorce}

Children of divorced parents have about $20 \%-35 \%$ rate of evidencing adjustment problems, compared to $12 \%$ (some studies suggest as much as 15\%) in married families (Braver \& Lamb, in press). Thus, the majority of children from divorced families evidence no psychopathology or behavioral symptoms, although they are likely to experience psychic pain for at least some time (Laumann-Billings \& Emery, 2000). There is a very high degree of variability found in responses of children and families to divorce. These dramatic individual differences in outcomes have prompted a close examination of the primary factors that research finds mediates 
child adjustment postdivorce. These factors consistently identified by research (Braver, Hipke, Ellman, \& Sandler, 2004; Amato, 2001; Braver \& Lamb, in press) are (roughly in order of importance): (1) the nature of the relationship between the two parents; (2) the custodial parent's functioning and parenting of the child; (3) the quality of the noncustodial parent's relationship to the child; (4) the characteristics of the child, in terms of coping, resilience, and temperament; and (5) the level-and change in level-of economic circumstances of the custodial parent. Although the child's characteristics are important, for any given family, they are a constant whatever the custody decision. Hence, we don't consider this factor further here. Similarly, we don't consider economic circumstances further, but for a different reason. Although the child's economic level after divorce is important, courts tend to prefer to disallow this factor as a consideration in awarding custody (for example, by awarding custody to the more economically well-off parent) and prefer attempts to alter these circumstances through child support orders (Ellman et al., 2010). Instead, our further focus is on the first three factors, which can profitably be used by courts and evaluators to choose a custody arrangement.

\section{Nature of the interparental relationship postdivorce}

Interparental conflict in divorced families is generally thought to be the most detrimental mediator of child outcome (e.g., Grych \& Fincham, 1990). Parental conflict is associated with a number of negative child outcomes including externalizing problems such as conduct disorder, aggression, delinquency, and antisocial behavior, as well as internalizing problems such as depression and anxiety (Grych \& Fincham, 1990). Although interparental conflict is certainly not unique to divorce, Hetherington and Stanley-Hagan (1999) suggest that high levels of conflict are even more detrimental to children of divorced parents than high levels of conflict in still married couples because there are fewer resources available to the children during a time of increased life stressors. Postdivorce conflict can be especially harmful to children because it is frequently centered on the child-related issues, including disagreements over child custody, child support, and visitation (Hetherington \& Stanley-Hagan, 1999). Research shows that high hostility and discord among parents who have low cooperative communication results in children feeling caught between their parents, which is related to poor adjustment outcomes (Buchanan, Maccoby, \& Dornbusch, 1991). Given the potential influence of interparental conflict on children's adjustment, custody arrangements and resolution processes that shield the children from conflict, and those that work against encouraging hostile alliances against the other parent, and focus on not pulling the children into the conflict are very desirable (Grych \& Fincham, 1990; Hetherington \& Stanley-Hagan, 1999).

On the reverse side, children also appear to greatly benefit from cooperative parenting. Cooperative parenting, or coparenting, is more than the absence of conflict. It is cooperative, mutually supportive, and nonconfrontational parenting (Hetherington, Bridges, \& Insabella, 1998). Successful coparenting involves showing respect for the other parent, maintaining open and useful dialog about the children, and sharing child-rearing tasks (Whiteside, 1998). Studies have linked successful coparenting with improved psychological functioning, academic performance, social competence, and lower levels of externalizing and internalizing symptoms in children of divorced parents (e.g., Buchanan et al., 1991). Unfortunately, cooperative parenting 
can be difficult for many parents to achieve postdivorce. A little more than $50 \%$ of parents postdivorce report an excellent or cooperative coparenting relations, but the rest of divorced parents report a relationship that includes inadequate support and some tension or intense difficulties and conflict (Whiteside, 1998).

Custodial parent's functioning and parenting of the child

Various studies support the finding that parenting issues are likely a cause of child maladjustment and behavior problems postdivorce (Forgatch \& DeGarmo, 1999). Since the primary custodial parent has the largest parenting role, the level of both emotional support and parental authority s/he provides as the family transitions through the stressful divorce process is crucial. Postdivorce children need parents who are authoritative: supportive, responsive, and communicative, and yet exerting firm and consistent control and discipline as well as close monitoring (Hetherington \& Stanley-Hagan, 1999). Authoritative parenting is linked with high social competence and fewer behavior problems (Hetherington et al., 1998). In addition, studies have shown that children of custodial parents with positive parenting qualities have higher self-esteem and better academic performance (Wyman, Sandler, Wolchik, \& Nelson, 2000).

Unfortunately, postdivorce parents themselves often suffer from an increased risk of psychological problems such as depression, anxiety, irritability, and impulsive behaviors, which limits their ability to be responsive and sensitive parents during a time when children can be especially demanding and difficult (Hetherington \& Stanley-Hagan, 1999). However, research suggests that many of these problems diminish by two years after the divorce as the parent's emotional state improves and as the family restabilizes, which improves the overall quality of parenting (Hetherington \& Stanley-Hagan, 1999).

Quality of the noncustodial parent's relationship to the child

Noncustodial parents continue to play a vital role in their children's lives and well-being. According to Amato and Gilbreth's meta-analysis (1999), it is not only contact with fathers but feelings of closeness between fathers and children and authoritative parenting that are positively associated with child well-being such as higher academic achievement and decreased internalizing and externalizing problems. It is the quality, not the quantity, of contact with the noncustodial father that is vital. Children do best with noncustodial parents who are actively involved in their children's lives beyond providing "treats" and fun activities when they visit. It is important that they be involved in their children's daily lives and participate in extracurricular activities, and enforcement of responsibilities including homework and chores, discipline, etc. (Braver \& Lamb, in press; Warshak, 2000). This involvement will increase the quality of the noncustodial parent-child relationship (Amato \& Gilbreth, 1999). Research also shows beneficial secondary effects from increased involvement, including increased child support payments, which reduces economic complications for custodial parents and children, improving their relationships (Warshak, 2000). Studies have also shown that increased child support payments are positively associated with children's academic success and inversely with externalizing problems (Amato \& Gilbreth, 1999). 


\section{Assessment Instruments Currently Used in Custody Evaluations}

We next consider the current state of assessment tools commonly used in child custody evaluations, with special attention to their scientific validity. These tools include various types of family observations, structured interviews, and psychological testing instruments (Keilin \& Bloom, 1986). With respect to the first, observations of family interaction lack standardization and uniformity across professionals and no studies exist to determine if they are reliable or valid. Concerning structured interviews, no validated protocols for custody evaluation based on empirical research currently exist (Gould \& Stahl, 2000). Finally, no psychological tests currently in widespread use have been found to have adequate levels of reliability or validity for purposes of deciding on a suitable custody arrangement.

By far the most common tests used in custody evaluations are IQ tests and the MMPI (Ackerman \& Ackerman, 1997). Although both have excellent psychometric qualities generally, neither assesses the qualities most at stake in custody evaluations, and hence have no demonstrated validity in that context. General projective tests, such as the Rorschach Inkblot Technique, Thematic Apperception Test, and Sentence Completion Test, are the next most often used (Ackerman \& Ackerman, 1997). These instruments have been sharply criticized in the scientific literature, and have shown little, if any, empirical support for their validity (Erickson, Lilienfeld, $\&$ Vitacco, 2007). Despite lack of scientific validity, current assessments remain infrequently challenged for use in court (Shuman, 2002). The Bricklin Scales (Bricklin, 1984) were developed specifically for child custody, yet remain criticized for a near-complete absence of data supporting their reliability and validity (Emery et at, 2005). In general, both the attributes measured and the instruments employed have elicited a legion of critics skeptical of the scientific basis of custody evaluations (Bow \& Quinell, 2004; Emery et at, 2005; Kelly \& Ramsey, 2009; Tippins \& Wittman, 2005).

\section{What Should and Could Be Assessed In Custody Evaluations}

Note, however, that conspicuously lacking in the list above is the attempt to measure the qualities that are demonstrably linked to child outcomes. As mentioned earlier, the focus should be instead on constructs associated with positive child outcome variables identified by existing research findings: indicators of both child maladjustment (such as mental health problems), and developmental competence (Masten \& Coatsworth, 1998) (such as indicators of success in developmental tasks like school or employment). There is a large, consistent, and impressive literature (reviewed above) that has linked the interparental relationship, custodial and noncustodial parenting, to both short- and long-term child well-being. To arrive at these scientific conclusions (and pass peer-review), the empirical research had to reliably and validly measure the constructs found to have desirable effects on child well-being. In other words, the research not only points to the factors implicated, it perforce must have assessed these factors with psychometrically sound instruments; or else it couldn't have reached the strong conclusions it did (Shadish, Cook, \& Campbell, 2002). To put it otherwise, all the results finding significant relationships with child well-being outcomes simultaneously identified and verified the relationship as well as provided construct validity evidence for the instruments that measured these variables. 
What are these validated measures? What scales do we assert should be used in custody evaluations, in place of the at-best questionable instruments typically employed? The first construct, parental conflict, has been repeatedly and validly assessed by the O'Leary Porter Scale (Porter \& O'Leary, 1980), the Conflict Tactics Scales (CTS; Straus, 1979), the Revised Conflict Tactics Scales (CTS2; Straus, Hamby, Boney-McCoy, \& Sugarman, 1996), the Divorce Conflict Measure (DCM; Nicholas, Slater, Forehand, \& Fauber, 1988), the Marital Problems Questionnaire (MPQ; Douglass \& Douglass, 1995), and the Conflicts and Problem-Solving Scales (CPS; Kerig, 1996). The child's view of parental conflict has been assessed with the Children's Perception of Interparental Conflict Scale (CPIC; Crych, Seid, \& Fincham, 1992), and the Post-Divorce Parental Conflict Scale (PPCS; Morris \& West, 2001), while others have used questionnaires to assess frequency of conflict, both overt and covert, by creating some new items and combining or adapting items from Ahrons (1981) and Crych et al. (1992). The Berkley Puppet Interview (Ablow, Measelle, Cowan, \& Cowan, 2009), designed to investigate young children's perceptions of the family environment, has also shown that it is valid for capturing marital conflict. Others, such as the Couple Communication Questionnaire (CCQ; Cowan \& Cowan, 1990a) include subscales on conflict but also ask about broader issues such as problem-solving and intimacy. The Interparental Conflict Scale (ICS; Black \& Pedro-Carroll, 1993) asks young adults retrospectively about parental conflict when growing up and includes 4 items from Ahrons' (1981) Coparent Communication Scale.

Coparenting refers to the ways in which parents coordinate their parenting, manage conflict regarding child rearing, and mutually support versus undermine each other (McHale, Kuersten-Hogan, Lauretti, \& Rasmussen, 2000), and has been strongly related to child outcomes (Abidin \& Brunner, 1995). (For a more detailed discussion of coparenting see Palkovitz \& Fagan, this volume.) Coparenting has been well-measured via parent report on the Parenting Alliance Inventory (PAI; Abidin \& Brunner, 1995), Perceptions of Coparenting Partners Questionnaire (Stright \& Bales, 2003), the Coparenting Questionnaire (Margolin, Cordis, \& John, 2001), and the Coparent Communication Scale (Ahrons, 1981). Coparental involvement and division of labor has been measured by the Who Does What? questionnaire (WDW; Cowan \& Cowan, 1990b). Parents also have conflict over coparenting, which has been assessed via the Child Rearing Issues: Self and Spouse Scale (Hetherington \& Clingempeel, 1992), and The Acrimony Scale (AS; Shaw \& Emery, 1987). Coparenting can be observationally coded as well (Belsky, Crnic, \& Cable, 1992).

An apparent difficulty with the constructs of interparental conflict and coparenting is that conflict is typically measured at the dyadic level, and thought of as a couple-level construct ("it takes two to tango"). As such, it might be thought useless in choosing between the parents. In fact, experienced divorce professionals are beginning to recognize that postdivorce conflict isn't always, or even commonly, mutual. For example, Kelly and Emery (2003) argue that

although high conflict postdivorce is generally assumed to be a shared interaction between two angry, culpable parents, our clinical, mediation, and arbitration experience in high-conflict postdivorce cases indicates that it is not uncommon to find one enraged or defiant parent and a second parent who no longer harbors anger, has 
emotionally disengaged, and attempts to avoid or mute conflict that involves the child. (p. 353)

Thus, attention should turn to identifying which of the parents is contentious and fomenting conflict. Efforts with parental report measures to identify which of two divorcing parents is most to blame for conflict haven't been promising thus far (Cookston, Griffin, Braver, \& Williams, 2004; each largely accuses the other). However, observational measures, such as the Marital Daily Record coding system (MDR; Cummings, Goeke-Morey, Papp, \& Dukewich, 2002), and semistructured interviews of children and parents (Crockenberg \& Langrock, 2001) have proved more successful. Child report has yielded some promising results as well (Braver, Coatsworth, \& Peralta, 2006). In any event, the quote above suggests that experienced professionals can readily detect whether the conflict is most commonly instigated be the mother, the father, or both. An inter-rater reliability study of this assertion should certainly be high on the research agenda.

Parenting has been measured well in numerous studies. Parenting encompasses a variety of constructs and the distinction is often made between parenting style and parenting practices. Parenting style is viewed as a parent's attitude toward parenting, expressed across situations, that provides an emotional climate for the parent-child relationship, whereas parenting practices refers to specific behaviors (often goal-directed) that parents exhibit toward their child, and may be situation-specific (Darling \& Steinberg, 1993). Parenting styles have long been derived from Baumrind (1971) and Maccoby and Martin (1983) by grouping parents into four categories based on levels of parental demandingness and responsiveness: Authoritative, Authoritarian, Indulgent (Permissive), and Uninvolved (Indifferent). Of these, authoritative parents have by far the children with the best outcomes on a variety of arenas. Validated measures of self-reported style of parenting include the Parenting Styles and Dimensions Questionnaire (PSDQ; Robinson, Mandelco, Olsen, \& Hart, 2001), the Parental Authority Questionnaire - Revised (Reitman, Rhode, Hupp, \& Altobello, 2002), and by combining measures of parenting with respect to demandingness and responsiveness. Broad measures of parenting include the Parenting Scale (Arnold, O'Leary, Wolff, \& Acker, 1992), the Parenting Knowledge Test (Gordon, 1994), Child Rearing Practices Report (CRPR; Roberts, Block, \& Block, 1984), Parenting Behaviour Checklist (PBC; Fox, 1994), Parenting Behavior Questionnaire (Hart, Nelson, Robinson, Olsen, \& McNeilly-Choque, 1998), the Child Report of Parent Behavior Inventory (CRPBI; Schaefer, 1965), the Parent Child Relationship Inventory (PCRI; Gerard, 1994), and the Family Environment Scales (FES; Moos \& Moos, 1994). Parental monitoring of their children is also strongly related to child outcomes and has been measured with the Assessment of Child Monitoring Scale (Hetherington \& Clingempeel, 1992) and the Parental Monitoring Scale (PMS; Small \& Kerns, 1993). Others have developed similar items that capture child disclosure, parental knowledge and parental solicitation as important constructs to monitoring (Stattin \& Kerr, 2000). Numerous studies have used observational measures of parenting behavior, such as the Iowa Family Interaction Rating Scales (Melby et al., 1990) and the HOME Inventory (Bradley, \& Caldwell, 1984); however, home observations require time-consuming coding, typically of videotaped observations, and time-consuming training of coders to achieve reliability 
for live and videotaped interaction. (See Holden \& Miller, 1999, for a more complete discussion of parenting constructs.)

Importantly, tests that reliably and validly assess a construct, such as parenting, in a general research context may not be so in a forensic custody evaluation context. Careful attention needs to be paid to validating research instruments for use in custody decisions with respect to response style and validity as well as documenting the appropriate norms for a forensic population.

\section{Custody Assessments Are a Snapshot in Time of Changing or Changeable Characteristics}

Careful readers following our arguments might conclude that we strongly recommend that courts and divorce professionals such as custody evaluators seek to assess, in contrast to current practice, the level of and initiator of interparental conflict, as well as the two parents' parenting skills, and that rigorous instruments exist to do so. This is not entirely correct; although we concur that the constructs in the sentence above are the correct ones to investigate in order to further the child's best interests, we also note that any assessment provides only a snapshot of parenting ability at a given point in time. The problem remains that even with good measures of parenting characteristics, mothers and fathers are under a great deal of stress (and distress) at the time of divorce, and thus this is likely not a representative point in time to provide information on their "true" parenting. In addition to distraught parents, the custody arrangements are soon to change through a divorce agreement, mediation, or court-ordered custody arrangement. Moreover, a parent with given characteristics, who is best able to parent the child now may not be the best parent 1,5 , or 10 years later, given that parenting practices show variation across time (Holden \& Miller, 1999). Indeed, changes in the appropriateness of parenting were similarly noted by Baumrind (1989, as cited in Holden \& Miller, 1999, p. 246):

... parents who are highly effective at one stage in the child's life are not necessarily as effective at another; . . . similar practices do not necessarily produce the same effects at successive stages in a child's life.

Moreover, the court system is not simply a measuring rod, attempting to impartially choose among competing alternatives. Like the Heisenberg principle, the very act of "assessing" within a court-room adversarial model has clear and generally negative impact on the characteristics assessed (Pruett \& Jackson, 1999). Parental conflict, the single best predictor of child outcomes (Lamb, in press; Kelly, in press) can be exacerbated when a contentious parent uses the legal system as an instrument of attack. That is an unavoidable possibility, even when courts attempt to discourage it, because courts have no choice, when parents refuse to settle their differences, but to allow them each to present the evidence and the arguments they believe will show that the other would be a poor choice of custodian. This conflict, as well as the stress that accompanies prolonged and circuitous negotiation and uncertainty, also has been shown to diminish the parenting capabilities of both parents (Emery et al., 2005). This implies that courts should devise and reform procedures to minimize these undesirable unintended 
consequences and instead to maximize the parents' resources and cooperative parenting. Many such programs are documented in Applegate (this volume).

\section{Interventions to Improve Child Outcomes after Divorce}

Parenting is a skill that is mutable and a number of parent training programs have proven astonishingly successful at improving parenting in divorcing families. For example, Parent Management Training (PMT) improved effective parenting, which in turn led to positive changes in child behavior (Patterson, DeGarmo, \& Forgatch, 2004), including child internalizing, externalizing, better school adjustment and less delinquency, and reduced child ratings of depression (Forgatch \& DeGarmo, 1999). Another program, the New Beginnings Program (NBP), has shown program-induced reductions in child behavior problems (internalizing, externalizing, drug use, number of sexual partners), improved mother-child relationship quality, effective parenting and discipline, and increased GPA (Zhou, Sandler, Millsap, Wolchik, \& Dawson-McClure, 2008). Most impressively, children whose parents underwent this program retained their substantial well-being advantage over children in the control condition six-years later (McClain, Wolchik, Winslow, Tein, Sandler, \& Millsap, 2010; Wolchik, Schenck, \& Sandler, 2009). The NBP is currently undergoing a redesign to include sessions for fathers as well as planned for a large-scale effectiveness trial in collaboration with the family courts (Wolchik et al., 2009). A third program, the Collaborative Divorce Project, has shown promise in decreased mothers' gatekeeping, reduced interparental conflict, increased positive father involvement, reduced child problems, increased interparental cooperation as reported by attorneys, and an increased likelihood of paying child support (Pruett, Insabella, \& Gustafson, 2005). Finally, the Dads for Life program, designed expressly for noncustodial fathers, has shown remarkable success in improving children's outcomes (Braver, Griffin, \& Cookston, 2005; Cookston, Braver, Griffin, DeLuse, \& Miles, 2007).

\section{Bridges to Other Disciplines}

Divorce and child custody, by their very nature, necessitate interdisciplinary participation from the court system, legal policy and research, social work, custody evaluators, and psychological research from a wide range of areas. We hope it is evident from our review that a great deal of collaboration already exists across multiple disciplines, with the overarching goal of promoting the best possible outcomes for children and families. Particularly fruitful has been the ongoing relationship between courts and programmatic interventions for families undergoing divorce. However, developmental psychology and family studies have much to offer the development of custody evaluation methods, particularly in terms of assessment of constructs known to relate to children's' well-being following divorce.

\section{Policy Implications}

Courts and custody evaluators will better evaluate the child's best interest if the use of instruments of questionable value is eliminated and the use of empirically validated instruments that 
measure interparental conflict, parenting by the mother and parenting by the father is increased. We do not suggest statutory revisions that would lock in a preference for some measures over others, but our discussion of the relation of these three factors to child well-being suggests that it would be appropriate for courts to give these measures more weight than others in custody determinations. The number of validated instruments already available suggests that a transition among professionals to more empirically validated measures of interparental conflict and parenting abilities would be relatively straightforward.

Indeed the benefits of incorporating empirical measures on conflict and parenting into divorce proceedings are many. Increased use of objective measurements (with careful attention to reporter bias) would strengthen courts and evaluators against criticism of partiality in making child custody determinations (although the accumulated clinical expertise and observations of a custody evaluator remains crucial to any determination of custody), and may decrease the number of couples who choose to extend their custody battles. In addition, the use of empirically valid measures of interparental conflict and parenting would greatly improve researchers' abilities to investigate determinants of child custody decisions, enable meaningful comparison across custody evaluations, and more reliably document the effects of custody plans and intervention programs on parental conflict and parenting practices.

\section{Future Directions}

A clear priority for professionals wishing to follow the recommendations in this chapter is to validate research measures in a forensic setting. We also contend it would be shortsighted to stop with simply substituting rigorous measures for the faulty ones currently in use. For example, even if one could validly identify a single conflict-instigating parent, one cannot assume that awarding more custodial time to the other parent will alone stop parental behavior that is harmful to the child. Courts need not limit themselves to choosing between alternative arrangements but can also improve the available alternatives by requiring parents' participation in programs that improve parenting and children's outcomes. The child's interests favor extending the judicial role from adjudicator between contending parties to include facilitating such participation in programs of established validity. Many family courts are already willing to assume this "therapeutic jurisprudence" role (Cookston, Sandler, Braver, \& Genalo, 2007). Indeed, custody evaluations could include recommendations for specific therapeutic programs depending on the issues present in a given separating family. More and more, courts are partnering with behavioral science researchers to develop systems and procedures that cannot merely choose among litigants but improve outcomes for children of divorcing families (Rita, Braver, Sandler, Knox, \& Strehle, 2009). As a result of these developments, we believe the future looks brighter for divorcing fathers and children (and mothers). 


\section{References}

Abidin, R. R., \& Brunner, J. F. (1995). Development of a parenting alliance inventory. Journal of Clinical Child Psychology, 24, 31-40.

Ablow, J. C., Measelle, J. R., Cowan, P. A., \& Cowan, C. P. (2009). Linking marital conflict and children's adjustment: The role of young children's perceptions. Journal of Family Psychology, 23(4), 485-499. doi: 10.1037/a0015894.

Ackerman, M. J., \& Ackerman, M. C. (1997). Child custody evaluation practices: A survey of experienced professionals (revisited). Professional Psychology: Research \& Practice, 28(2), 137-145.

Ahrons, C. R. (1981). The continuing coparental relationship between divorced spouses. American Journal of Orthopsychiatry, 5, 415-428.

Amato, P. R. (2001). Children of divorce in the 1990s: An update of the Amato and Keith (1991) metaanalysis. Journal of Family Psychology, 15(3), 355-370.

Amato, P. R., \& Gilbreth, J. G. (1999). Nonresident fathers and children's well-being: A meta-analysis. Journal of Marriage and the Family, 61(3), 557-573. doi: 10.2307/353560

Arbuthnot, J. (2002). A call unheeded: Courts' perceived obstacles to establishing divorce education programs. Family Court Review, 40, 371-382.

Argys, L. H., Peters, E. Cook, S. Garasky, S., Nepomnyaschy, L., \& Sorensen, E. (2007). Measuring contact between children and nonresident fathers. In S. Hofferth \& L. Casper (Eds.), Handbook of measurement issues in family research. Mahwah, NJ: Erlbaum.

Arnold, D. S., O'Leary, S. G., Wolff, L. S., \& Acker, M. M. (1992). The parenting scale: A measure of dysfunctional parenting in discipline situations. Psychological Assessment, 4, 66-83.

Baumrind, D. (1971). Current patterns of parental authority. Developmental Psychology Monograph, 4, 1-103.

Baumrind, D. (1989). The permanence of change and the impermanence of stability. Human Development, 32, 187-195.

Belsky, J., Crnic, K., \& Gable, S. (1992). Manual for coding coparenting. Pennsylvania State Child and Family Development Project, University Park, Pennsylvania State University.

Black, A. E., \& Pedro-Carroll, J. (1993). Role of parent-child relationships in mediating the effects of marital disruption. Journal of the American Academy of Child and Adolescent Psychiatry, 32(5), 1019-1027.

Bow, J. M., \& Quinell, F. A. (2004). Critique of child custody evaluations by the legal profession. Family Court Review, 42(1), 115-127.

Bradley, R. H., \& Caldwell, B. M. (1984). The HOME inventory and family demographics. Developmental Psychology, 20, 315-320.

Braver, S. L., Coatsworth, D., \& Peralta, K. (2006). Alienating behavior within divorced and intact families: Matched parents' and now-young adult children's reports. Presented at International Conference on Children and Divorce (ICCD), Norwich, UK.

Braver, S. L., Griffin, W. A., \& Cookston, J. T (2005). Prevention programs for divorced nonresident fathers. Family Court Review, 43(1), 81-96. doi: 10.1111/j.1744-1617.2005.00009.x

Braver, S. L., Hipke, K. N., Ellman, I. M., \& Sandler, I. N. (2004). In K. I. Maton, C. J. Schellenbach, B. J. Leadbeater, \& A. L. Solarz (Eds.), Strength-building public policy for children of divorce (pp. 53-72). Washington, DC: American Psychological Association.

Braver, S. L., \& Lamb, M. E. (in press). Marital dissolution. In G. W. Peterson \& K. R. Bush (Eds.), Handbook of marriage and the family (2nd ed.). New York: Springer.

Braver, S. L., \& O'Connell, D. (1998). Divorced dads: Shattering the myths. New York: Tarcher/Putnam. 
Braver, S. L., Shapiro, J. R., \& Goodman, M. R. (2005). The consequences of divorce for parents. In M. A. Fine \& J. H. Harvey (Eds.), Handbook of divorce and relationship dissolution (pp. 313-337). Mahwah, NJ: Erlbaum.

Bricklin, B. (1984). Bricklin perceptual scales. Furlong, PA: Village.

Brown, P., \& Cancian, M. (2007). Wisconsin's 2004 shared-physical-placement guidelines: Their use and implications in divorce cases. University of Wisconsin-Madison: Institute for Research on Poverty.

Buchanan, C. M., Maccoby, E. E., \& Dornbusch, S. M. (1991). Caught between parents: Adolescents' experience in divorced homes. Child Development, 62, 1008-1029.

Chambers, D. L. (1984). Rethinking the substantive rules for custody disputes in divorce. Michigan Law Review, 83, 477-569.

Cherlin, A. (2010). Demographic trends in the United States: A review of research in the 2000s, Journal of Marriage and the Family, 72, 403-419.

Cookston, J. T, Braver, S. L., Griffin, W. A., DeLuse, S. R., \& Miles, J. C. (2007). Effects of the Dads For Life intervention on coparenting in the two years after divorce. Family Process, 46(1), 123-137.

Cookston, J. T, Griffin, W. A., Braver, S. L., \& Williams, J. (2004). Predicting interparent conflict and child outcomes following divorce: The role of parent argument behaviors. Unpublished manuscript.

Cookston, J. T, Sandler, I. N., Braver, S. L., \& Genalo, M. T (2007). Predicting readiness to adopt evidencebased programs for divorcing families: Champions, attitudes, and access to funding. American Journal of Orthopsychiatry, 77(4), 573-581.

Cowan, C. P., \& Cowan, P. A. (1990a). Couple communication questionnaire. Berkeley: Institute of Human Development, University of California.

Cowan, P. A., \& Cowan, C. P. (1990b). Who does what? In J. F. Touliatos, B. F. Perlmutter, \& M. A. Straus (Eds.), Handbook of family measurement techniques (pp. 447-448). Thousand Oaks, CA: Sage.

Cox, M., \& Paley, B. (1997). Families as systems. Annual Review of Psychology, 48, 243-267.

Crockenberg, S., \& Langrock, A. (2001). The role of specific emotions in children's responses to interparental conflict: A test of the model. Journal of Family Psychology, 15, 163-182.

Cummings, E. M., Goeke-Morey, M. C., Papp, L. M., \& Dukewich, T. L. (2002). Children's responses to mothers' and fathers' emotionality and tactics in marital conflict in the home. Journal of Family Psychology, 16, 478-492.

Darling, N., \& Steinberg, L. (1993). Parenting style as context: An integrative model. Psychological Bulletin, 113(3), 487-496. doi: 10.1037/0033-2909.113.3.487

DeLusé, S. R. (1999). Mandatory divorce education: A program evaluation using a "quasi-random" regression discontinuity design. Doctoral dissertation, Arizona State University. Dissertation Abstracts International, 60, 13-49.

Douglas, E. M. (2003). The effect of a presumption for joint legal custody on father involvement in divorced families. Journal of Divorce and Remarriage, 40(3/4), 1-10.

Douglass, F. M., \& Douglass, R. (1995). The marital problems questionnaire (MPQ): A short screening instrument for marital therapy. Family Relations, 44, 238-244.

Ellman, I. M. (1999a). The maturing law of divorce finances: Toward rules and guidelines. Family Law Quarterly, 33(3), 801-814.

Ellman, I. M. (1999b). Brigitte M. Bodenheimer memorial lecture on the family: Inventing family law, University of California Davis Law Review, 32, 855-886.

Ellman, I. M. (2003). Why making family law is hard. Arizona State Law Journal, 35, 699-714. 
Ellman, I. M., Kurtz, P. M., Weithorn, L. A., Bix, B. H., Czapanskiy, K., \& Eichner, M. (2010). Family law: Cases, text, problems (5th ed.). New Providence, NJ: LexisNexis.

Emery, R. E., Otto, R. K., \& O’Donohue, W. T. (2005). A critical assessment of child custody evaluations: Limited science and a flawed system. Psychological Science in the Public Interest, 6(1), 1-29.

Erickson, S. K., Lilienfeld, S. O., \& Vitacco, M. J. (2007). Failing the burden of proof: The science and ethics of projective tests in custody evaluations. Family Court Review, 45(2), 185-192.

Fabricius, W. V., Braver, S. L., Diaz, P., \& Velez, C. E. (2010). Custody and parenting time: Links to family relationships and well-being after divorce. In M. E. Lamb (Ed.), The Role of the Father in Child Development (5th ed., pp. 201-240. New York: Wiley.

Forgatch, M. S., \& DeGarmo, D. S. (1999). Parenting through change: An effective prevention program for single mothers. Journal of Consulting and Clinical Psychology, 67, 711-724.

Fox, R. (1994). Parent behaviour checklist. Brandon, VT: Clinical Psychology Publishing Co.

George, T. (2008). Residential time summary reports filed in Washington from July 2007-March 2008. Olympia: Administrative Office of the Courts: Washington State Center for Court Research.

Gerard, A. B. (1994). The parent-child relationship inventory. Los Angeles: Western Psychological Services.

Goodman, M., Bonds, D., Sandler, I. N., \& Braver, S. L. (2004). Parent psychoeducational programs and reducing the negative effects of interparental conflict following divorce. Family Court Review, 42(2), 263-279.

Gordon, T. (1994). Parenting knowledge test. Unpublished measure. Ohio University, Athens.

Gould, J. W., \& Martindale, D. A. (2007). The art and science of child custody evaluations. New York: Guilford Press.

Gould, J. W., \& Stahl, P. M. (2000). The art and science of child custody evaluations: Integrating clinical and forensic mental health models [Special issue: Child Custody Evaluations]. Family E Conciliation Courts Review, 38(3), 392-414.

Grych, J. H., \& Fincham, F. D. (1990). Marital conflict and children's adjustment: A cognitive-contextual framework. Psychological Bulletin, 108(2), 267-290. doi: 10.1037/0033-2909.108.2.267

Grych, J. H., Seid, M., \& Fincham, F. D. (1992). Assessing marital conflict from the child's perspective: The children's perception of interparental conflict scale. Child Development, 63, 558-572.

Hart, C. H., Nelson, D. A., Robinson, C. C., Olsen, S. F., \& McNeilly-Choque, M. K. (1998). Overt and relational aggression in Russian nursery school-age children: Parenting style and marital linkages. Developmental Psychology, 34(4), 687-697.

Hetherington, E. M., Bridges, M., \& Insabella, C. M. (1998). What matters? What does Not? Five perspectives on the association between marital transitions and children's adjustment. American Psychologist, 53(2), 167-184. doi: 10.1037/0003-6X.53.2.167

Hetherington, E. M., \& Clingempeel, C. (1992). Coping with marital transitions: A family systems perspective. Monographs of the Society for Research in Child Development, 57(2-3).

Hetherington, E. M., \& Stanley-Hagan, M. (1999). The adjustment of children with divorced parents: A risk and resiliency perspective. Journal of Child Psychology and Psychiatry and Allied Disciplines 40(1), 129-140. doi: 10.1111/1469-7610.00427

Hita, L. C.; Braver, S. L., Sandler, I. N., Knox, P., \& Strehle, M. (2009). Family court-university partnership to benefit divorcing families: The experience of Maricopa County (Arizona) Family Court Department and Arizona State University's Prevention Research Center. Family Court Review, 47(3), 436-450.

Holden, C. W., \& Miller, P. C. (1999). Enduring and different: A meta-analysis of the similarity in parents' child rearing. Psychological Bulletin, 125(2), 223-254. 
Keilin, W. C., \& Bloom, L. J. (1986). Child custody evaluation practices: A survey of experienced professionals. Professional Psychology: Research and Practice, 17, 338-346.

Kelly, J. B. (2007). Children's living arrangements following separation and divorce: Insights from empirical and clinical research. Family Process, 46, 35-52.

Kelly, J. B. (in press). Risk and protective factors associated with child and adolescent adjustment following separation and divorce: Social science applications. In K. Kuehnle \& L. Drozd (Eds.), Parenting plan evaluations: Applied research for the family court. New York: Oxford University Press.

Kelly, J. B., \& Emery, R. E. (2003). Children's adjustment following divorce: Risk and resilience perspectives. Family Relations, 52, 352-362.

Kelly, R. F., \& Ramsey, S. H. (2009). Child custody evaluations: The need for systems-level outcome assessments. Family Court Review, 47(2), 286-303. doi: 10.1111/j.1744-1617.2009.01255.x

Kerig, P. K. (1996). Assessing the links between interparental conflict and child adjustment: The conflicts and problem-solving scales. Journal of Family Psychology, 10(4), 454-473.

Lamb, M. E. (in press) Critical analysis of research on parenting plans and children's well-being. In K. Kuehnle \& L. Drozd (Eds.), Parenting plan evaluations: Applied research for the family court. New York: Oxford University Press.

Laumann-Billings, L., \& Emery, R. E. (2000). Distress among young adults from divorced families. Journal of Family Psychology, 14, 671-687.

Maccoby, E. E., \& Martin, J. A. (1983). Socialization in the context of the family: Parent-child interaction. In P. Mussen (Ed.), Handbook of Child Psychology (pp. 1-101). New York: Wiley.

Maccoby, E. E., \& Mnookin, R. H. (1992). Dividing the child: Social and legal dilemmas of custody. Cambridge, MA: Harvard University Press.

Margolin, C., Cordis, E. B., \& John, R. S. (2001). Coparenting: A link between marital conflict and parenting in two-parent families. Journal of Family Psychology, 15, 3-21.

Mason, M. A. (1994). From father's property to children's rights: The history of child custody in the United States. New York: Columbia University Press.

Masten, A. S., \& Coatsworth, J. D. (1998). The development of competence in favorable and unfavorable environments: Lessons from research on successful children. American Psychologist, 53(2), $205-220$. doi: 10.1037/0003-066X.53.2.205

McClain, D. B., Wolchik, S. A., Winslow, E., Tein, J., Sandler, I. N., \& Millsap, R. E. (2010). Developmental cascade effects of the New Beginnings Program on adolescent adaptation outcomes. Development and Psychopathology, 22, 771-784. doi: 10.1017/S0954579410000453

McHale, J. P., Kuersten-Hogan, R., Lauretti, A., \& Rasmussen, J. L. (2000). Parental reports of coparenting and observed coparenting behavior during the toddler period. Journal of Family Psychology, 14(2), 220236. doi: 10.1037/0893-3200.14.2.220

Melby, J., Conger, R., Book, R., Rueter, M., Lucy, L., Repinski, D., et al. (1990). The Iowa family interaction coding manual. Ames, IA: Iowa Youth and Families Project.

Moos, R., \& Moos, B. (1994). Family environment scale manual (2nd ed.). Palo Alto, CA: Consulting Psychologists Press.

Morris, M. H., \& West, C. (2001). Post-Divorce conflict and avoidance of intimacy. Journal of Divorce $\mathcal{E}$ Remarriage, 35(3/4), 93-105.

Nicholas, L., Slater, E., Forehand, R., \& Fauber, R. (1988). Continued high or reduced interparental conflict following divorce: Relation to young adolescent adjustment. Journal of Consulting and Clinical Psychology, 56(3), 467-469. doi: 10.1037/0022-006X.56.3.467 
O'Connell, M. E. (2007). When noble aspirations fail: Why we need the Approximation Rule. Child Development Perspectives, 1, 129-131.

Paquette, D. (1994) Theorizing the father-child relationship: Mechanisms and developmental outcomes. Human Development, 47(4), 193-219. doi: 10.1159/000078723

Patterson, G. R., DeGarmo, D., \& Forgatch, M. S. (2004). Systematic changes in families following prevention trials. Journal of Abnormal Child Psychology, 32(6), 621-633.

Polikoff, N. D. (1982). Why are mothers losing: A brief analysis of criteria used in child custody determinations. Women's Rights Law Reporter, 14, 175-184.

Porter, B., \& O'Leary, D. (1980). Marital discord and childhood behavior problems. Journal of Abnormal Psychology, 8, 287-295.

Pruett, M. K., Insabella, G. M., \& Gustafson, K. (2005). The collaborative divorce project: A court-based intervention for separating parenting with young children. Family Court Review, 43, 38-51.

Pruett, M. K., \& Jackson, T. (1999). The lawyer's role during the divorce process. Perceptions of parents, their young children, and their attorneys. Family Law Quarterly, 33, 283-310.

Reitman, D., Rhode, P. C., Hupp, S. D. A., \& Altobello, C. (2002). Development and validation of the parental authority questionnaire-revised. Journal of Psychopathology and Behavior Assessment, 24, 119-127.

Roberts, G. C., Block, H., \& Block, J. (1984). Continuity and change in parents' child-rearing practices. Child Development, 55, 586-597.

Robinson, C. C., Mandelco, B., Olsen, S. F., \& Hart, C. H. (2001). Parenting styles and dimensions questionnaire. In B. F. Perlmutter, J. Touliatos \& G. W. Holdem (Eds.), Handbook of family measurement techniques: Instruments and index (pp. 319-321). Thousand Oaks, CA: Sage.

Schaefer, E. S. (1965). Children's report of parental behavior: An inventory. Child Development, 36, $413-424$.

Schepard, A. I. (2004). Children, courts, and custody: Interdisciplinary models for divorcing families. New York: Cambridge University Press.

Seltzer, J. A. (1990). Legal and physical custody arrangements in recent divorces. Social Science Quarterly, $71,250-266$.

Semple, N. (2011, June). The settlement mission in custody and access cases. Presented at Association of Family and Conciliation Courts, Orlando, Florida.

Shadish, W. R., Cook, T. D., \& Campbell, D. T. (2002). Experimental and quasi-experimental designs for generalized causal inference. Boston: Houghton-Mifflin.

Shaw, D., \& Emery, R. E. (1987). Parental conflict and the adjustment of school-aged children whose parents have separated. Journal of Abnormal Child Psychology, 15, 269-281.

Shuman, D. W. (2002). The role of mental health experts in custody decisions: Science, psychological tests, and clinical judgment. Family Law Quarterly, 36(1), 135-162.

Sigal, A., Sandler, I., Wolchik, S., \& Braver, S. L. (2011). Do parent education programs promote healthy post-divorce parenting? Critical distinctions and a review of the evidence. Family Court Review, 49(1), 120-139.

Small, S. A., \& Kerns, D. (1993). Unwanted sexual activity among peers during early and middle adolescence: Incidence and risk factors. Journal of Marriage and the Family, 55, 941-952.

Stattin, H., \& Kerr, M. (2000). Parental monitoring: A reinterpretation. Child Development, 71(4), 1072-1085.

Straus, M. A. (1979). Measuring intrafamily conflict and violence: The conflict tactics (CT) scales. Journal of Marriage and Family, 41(1), 75-88. 
Straus, M. A., Hamby, S. L., Boney-McCoy, S., \& Sugarman, D. B. (1996). The revised conflict tactics scales (CTS2). Journal of Family Issues, 17(3), 283-316.

Stright, A. D., \& Bales, S. S. (2003). Coparenting quality: Contributions of child and parent characteristics. Family Relations, 52(3), 232-240.

Tippins, T. M., \& Wittman, J. P. (2005). Empirical and ethical problems with custody recommendations: A call for clinical humility and judicial Vigilance. Family Court Review, 43(2), 193-222.

United Nations. (1989). Convention on the rights of the child. Retrieved November 26, 2008, from http://www.unhchr.ch/htmllmenu3/b/k2crc.htm

Venohr, J. C., \& Griffith, T. E. (2003). Arizona child support guidelines: Findings from a case file review. Denver, CO: Policy Studies.

Venohr, J. C., \& Griffith, T. E. (2005) Child support guidelines: Issues and reviews. Family Court Review, $43,415-428$.

Venohr, J. C., \& Kaunelis, R. (2008). Arizona child support guidelines review: Analysis of case file data. Denver, CO: Center for Policy Research.

Warshak, R. A. (2000). Social science and children's best interests in relocation cases: Burgess revisited. Law Quarterly, 34(1), 83-113.

Warshak, R. A. (2007). Punching the parenting time clock: The Approximation Rule, social science, and the baseball bat kids. Family Court Review, 45(4), 600-619.

Whiteside, M. F. (1998). The parental alliance following divorce: An overview. Journal of Marital and Family Therapy, 24(1), 3-24. doi: 10.1111/j.1752-0606.1998.tb01060.x

Wolchik, S. A., Sandler, I. N., Jones, S., Gonzales, N., Doyle, K, Winslow, E., et al. (2009). The New Beginnings Program for divorcing and separating families: Moving from efficacy to effectiveness. Family Court Review, 47(3), 416-435.

Wolchik, S. A., Schenck, C. E., \& Sandler, I. N. (2009). Promoting resilience in youth from divorced families: Lessons learned from experimental trials of the New Beginnings Program. Journal of Personality, 77(6), 1833-1868. doi: 10.1111/j.1467-6494.2009.00602.x

Wyman, P. A., Sandler, I. N., Wolchik, S. A., \& Nelson, K. A. (2000). Resilience as cumulative competence promotion and stress protection: Theory and intervention. In D. Cicchetti, J. Rappaport, I. N. Sandler, \& R. P. Weissberg (Eds.), The promotion of wellness in children and adolescents (pp. 133-184). Thousand Oaks, CA: Sage.

Zhou, Q., Sandler, I. N., Millsap, R. E., Wolchik, S. A., \& Dawson-McClure, S. R. (2008). Mother-child relationship quality and effective discipline as mediators of the 6-year effects of the new beginnings program for children from divorced families. Journal of Consulting and Clinical Psychology, 76(4), 579594. doi: 10.1037/0022-006X.76.4.579 